\title{
Maine Coast Winds
}

DE-FC36-99G0 10462

\section{Quarterly Report (Fall 99)}

January 28, 2000

\section{Summary}

The Maine Coast Winds Project was proposed for four possible turbine locations: Maine Maritime Academy (MMA), G.M. Allen blueberry processors, Island Acres farm, and Billings Marine and Diesel. The project has the option of installing either four Bergey Excels at each of those locations, or two Atlantic Orient 15/50s at two of the locations.

As of early January, we have made significant progress at the Allen location, having obtained a lease-power purchase contract for ten years for the installation of an AOC 15/50. We have completed most of the site planning and permitting, and have submitted a request to $\mathrm{DOE}$ for an advance towards the down payment to order the turbine and tower from AOC. We expect to install the turbine in early May.

We have found that the other three locations are less suitable for the project, and we are considering new locations for a second AOC 15/50. One good possibility is Deer Isle's new junior high school now under construction. Discussions with the school and other possible sites in the area continue.

\section{Allen Blueberry Site}

GM Allen \& Sons is a Maine wild blueberry grower and processor. The company harvests berries from its fields scattered around the Penobscot peninsula during the months of August and September and then processes and freezes them for sale to the institutional food market. Allen operates processing machinery and a large freezer at its plant. Allen's electricity usage averages 20,000 kilowatt hours most months, but jumps to more than 300,000 kwh in August. Allen has two electric services from Central Maine Power. The Allen plant is located on a hillside surrounded on three sides by fields and low tree stands, with good exposures in all directions. A county road runs by the plant and houses are sited on the far side of the road.

Maine is undergoing extensive electric restructuring with concomitant changes to rates. For the foreseeable future, Allen's electric tariffs include energy charges, energybased delivery charges, and demand charges. Allen currently pays between $\$ 0.07$ and $\$ 0.085$ per kwh for all energy-based charges.

Throughout our discussions, the manager of GM Allen \& Sons has been consistent in his response to our proposals. While he is intrigued by the wind turbine 


\section{DISCLAIMER}

This report was prepared as an account of work sponsored by an agency of the United States Government. Neither the United States Government nor any agency thereof, nor any of their employees, make any warranty, express or implied, or assumes any legal liability or responsibility for the accuracy, completeness, or usefulness of any information, apparatus, product, or process disclosed, or represents that its use would not infringe privately owned rights. Reference herein to any specific commercial product, process, or service by trade name, trademark, manufacturer, or otherwise does not necessarily constitute or imply its endorsement, recommendation, or favoring by the United States Government or any agency thereof. The views and opinions of authors expressed herein do not necessarily state or reflect those of the United States Government or any agency thereof. 


\section{DISCLAIMER}

\section{Portions of this document may be illegible in electronic image products. Images are produced from the best available original document.}


technology, he sees no business advantage to having the onsite turbine, and attaches little importance to the environmental benefits of wind energy. Therefore he would accept our proposal only if it cost him little or nothing, did not disrupt his operations, and did not call for any significant outlay of his company's time or energy. Our contract with Allen responds to his concerns by linking the power purchase price to his grid energy price, and by allocating insurance, tax, maintenance and other potential liabilities to us.

Site planning has been mostly completed. We have excavated a tower foundation test hole at a site 150 feet from the freezer building, and plotted out buried conduit runs and installation of electrical controls and interconnects inside the Allen freezer compressor room, near the service entrance. CMP currently has more than twenty similar net metering interconnected generators, and the $\mathrm{CMP}$ engineers do not anticipate a problem with the Allen installation. One of our tasks in the next month is to finalize the electrical engineering.

Orland, Maine, where the Allen plant is located, has only shoreland zoning (which does not apply to this site.) Therefore, the only local permitting required for the turbine installation is a "site plan review" undertaken by the town Planning Board. The review ordinance provides that the site permit must be granted unless, among other criteria, the project does not relate harmoniously to the existing terrain and buildings, or the project has an adverse audio or visual impact on surrounding properties. We have given an initial presentation of the project to the Planning Board and will have a public hearing in February, with a decision by the Board expected shortly afterwards. The only criticism we have heard to date is one comment about turbine noise.

We expect to receive the turbine, tower and blades from Atlantic Orient in late April. Prior to that date, we will complete the foundation and cable installation. Access to the site is good, and use of a crane for installation should pose no problems.

\section{Other Turbine Locations}

After further discussions with site owners and local officials, EEC has decided that the other three originally proposed turbine locations are not suitable for further development work right now, although they may be in the future.

Maine Maritime Academy's engineering faculty was very interested in the proposed turbine installation as a good learning tool for power generation technology and the environment. We met with the faculty and administration several times and agreed on a site on the Academy's grounds that had moderate wind exposure and fit in well with surrounding school activities. However, as we started discussing the project with Castine town officials, it became clear that despite the state institution's exemption from local zoning control, significant opposition to the turbine would probably arise from town residents. The downtown area of Castine, which extends from the waterfront up a hill to the Academy's grounds, has become a historic area filled with renovated old homes 
populated by wealthy retirees. Opposition to a wind turbine on aesthetic grounds was likely to be strong, well-funded and, even if overcome, a source of significant delay.

Billings Diesel is a good candidate for a wind turbine, because of its windy location at the southern tip of Deer Isle and electricity usage. However, as a busy shipyard with limited space and an ongoing expansion project, Billings decided to defer for the present on our turbine proposal. Based on our talks with town officials, zoning and public acceptance would not be a problem at Billings.

Island Acres farm remains a good site for a wind turbine, albeit one smaller than the AOC 15/50. Their annual electrical consumption is approximately $80,000 \mathrm{kwh}$, and as a typical hard-working, undercapitalized family farm they have little margin for new expenses or capital investments. The farm is best suited for a smaller turbine.

Deer Isle is building a new elementary and junior high school. School officials approached EEC to suggest a wind turbine and we have made an initial proposal for an installation similar to that of GM Allen. The new school site is an open area that slopes gradually to the west towards the shoreline half a mile distant. It has good wind exposure and no residences nearby.

There are other possible sites for a second $A O C$ turbine and we are contacting siteowners with proposals. It is likely that with favorable publicity and acceptance of the turbine at Allens after its installation this spring, other good turbine locations will be presented to us.

Richard Avery

Project Manager 